Published by Energy Efficiency, DOI: 10.1007/s12053-019-09828-5

\title{
The effects of behavioral intention on the choice to purchase energy-saving appliances in China: the role of environmental attitude, concern, and perceived psychological benefits in shaping intention
}

\author{
Xianchun Liao ${ }^{\mathrm{a}}$, Shiran Victoria Shen ${ }^{\mathrm{b}}$, Xunpeng (Roc) Shi*c,d,e \\ a Professor, Business School and Institute of Green Development, University of Jinan, Jinan, Shandong, 250022, \\ China. Email: liaoxian2@yahoo.com \\ b Assistant Professor of Environmental Politics, University of Virginia, 1540 Jefferson Park Ave, Charlottesville, \\ Virginia, USA 22904. Email: svshen@virginia.edu \\ ${ }^{c}$ *Corresponding author. Australia-China Relations Institute, University of Technology Sydney, Ultimo, NSW \\ 2007, Australia. Email: xunpeng.shi@gmail.com. \\ ${ }^{\mathrm{d}}$ Center of Hubei Cooperative Innovation for Emissions Trading System \& School of Low Carbon Economics, \\ Hubei University of Economics, Wuhan, Hubei Province, China 430205. \\ e Energy Studies Institute, National University of Singapore, Singapore 119620.
}

\section{Highlights}

- This paper integrates psychological benefits into the theory of planned behavior.

- $\quad$ This study is based on a cross-sectional online survey of 942 Chinese households conducted in 2016.

- Behavioral intention positively affects the choice to purchase energy-saving appliances.

- Environmental attitude and concern positively influence the intention to buy energy-saving appliances.

- $\quad$ First to reveal that perceived psychological benefits positively affect behavioral intention in China.

\begin{abstract}
Purchasing energy-saving appliances is a sensible and practical way to reduce carbon emissions from the residential sector in China. This study examines the relationship between pro-environment behavioral intention - undergirded by environmental attitude and concern as well as perceived psychological benefits - and the choice to purchase energy-saving appliances among Chinese households. Integrating psychological benefits (i.e., warm glow and self-express benefit) into the theory of planned behavior, a first of its kind for China, we designed and implemented a cross-sectional online survey in 2016. We conducted Probit regression analyses based on the 942 effective responses collected. The results reveal that behavioral intention has significantly positive effects on the choice to purchase energy-saving appliances. Environmental attitude and concern, as well as psychological benefits, have a significantly positive impact on respondents' behavioral intention to buy energy-saving devices. Also, age and household size significantly and positively correlate with purchasing energy-saving appliance decision. These results point to useful policy implications to boost consumer support for energy-saving appliances in China and provide a foundation for similar research in other developing contexts.
\end{abstract}

Keywords: energy-saving appliances; behavioral intention; environmental concern; psychological benefits; China 


\section{Introduction}

The extraordinary economic growth of China in the past four decades came at considerable environmental costs. In 2007, China eclipsed the United States to become the largest greenhouse gas emitter in the world (NEAA, 2008). Most of the 334 prefectural cities in China did not meet air quality standards recommended by the World Health Organization (China Environment Yearbook, 2016). Many Chinese cities rank among the most polluted cities globally (WHO, 2016). It was estimated that more than one million people died each year prematurely from air pollution in China (Pope III and Dockery, 2013; Lim et al., 2013). Geographically, researchers documented a 5.5-year gap in life expectancy between the heavily polluted north and the less dirty south (Chen et al., 2013). Temporally, the peak in local pollution cycles imposed high human costs (Shen, 2018).

The central government has made environmental protection a top priority. At the National People's Congress in 2014, Premier Li Keqiang declared the inception of China's "war on air pollution" (Reuters, 2014). Under the Thirteenth Five-Year Plan (2016-2020), the country aims to achieve a 15 percent reduction in energy intensity (i.e., energy consumption per unit of GDP) and an 18 percent decrease in carbon intensity (i.e., carbon emissions per unit of GDP). China also seeks to cap total energy consumption at 5 billion tons of standard coal equivalent by 2020 (Zheng et al., 2019). A national emissions trading scheme was launched in late 2017 (Sun et al., 2019), and significant efforts have been made to restructure the economy and upgrade technologies (Wang et al., 2019; Li et al., 2019).

In addition to the top-down measures, changing human behavior from the bottom up is another way to conserve energy. $\mathrm{CO}_{2}$ emissions from household energy consumption are 
estimated to contribute to 10-20 percent of global $\mathrm{CO}_{2}$ emissions (see, e.g., Long et al., 2018;

Grunert and Juhl, 1995). Such a significant share implies that consumers' purchasing behavior can play a critical role in curbing carbon emissions. A salient example of this is the purchasing and adoption of energy-saving appliances in China. Such appliances include solar water heaters, refrigerators, air conditioners, air purifiers, electric bikes, and electric vehicles, which are already subsidized by the Chinese government. ${ }^{1}$ However, energy-saving appliances are still underutilized among Chinese consumers. According to an Ali Research Report, "environmentally-friendly consumers" only accounted for 16 percent of all Ali consumers in 2015 (Ali Research Report, 2016). ${ }^{2}$

The literature on the purchasing behavior of energy-saving appliances exhibits at least three gaps. First, the findings of how environmental attitude and concern influence purchase intention are mixed, demanding more work on this increasingly critical and thriving area of research. For example, Gadenne et al. (2011) find that environmental attitude significantly affects energy-saving behavior in Australia. Similarly, Sapci and Considine (2014) reveal that households with more environmental concern tend to have lower energy use in Wyoming, USA. Hartmann and Apaolaza-Ibáñez (2012) also confirm that consumers' environmental concern has a significant influence on the intention to buy green energy brands in Spain. By contrast, Gaspar and Antunes (2011) display that neither general nor particular environmental attitudes have

1 The latest subsidy policy on household energy-saving appliances in 2017. http://www.jayall.com/article/73258.html.

2 The Ali platform hosts China's largest e-commerce market. 
significant influence on energy efficiency in Europe. Second, although previous studies have explored the impacts of residential intention on the choice to purchase energy-saving devices in developed countries like the USA (see Bang et al., 2000; Litvine and Wüstenhagen, 2011), much fewer works have examined the relationship in developing countries, particularly in China (Sapci and Considine, 2014). Among the few works on China, Chan and Lau (2000) find that ecological effect and knowledge have a significant and positive influence, but cultural values have only moderate effects among residents in Beijing and Guangzhou. Wang et al. (2011) indicate that environmental awareness does not influence electricity saving in households, while social norms, economic benefits, subsidy, and experience positively and significantly affect electricity-saving behavior in Beijing. Liu et al. (2012) find that information about energy-saving appliances and perception of self-responsibility affect substantially urban residents' actual green purchasing behaviors in Suzhou, Jiangsu Province. Finally, building on the first two points, existing literature suggests that the most critical factor in explaining environmental intention in developed countries such as Spain (Hartmann and Apaolaza-Ibáñez 2012) is related to psychological benefits; however, no such work has been performed for China.

In this study, we explore the determinants of the intention and the choice to purchase energy-saving appliances in Chinese households, considering environmental attitude, concern, and psychological benefits as the key determinants. Applying a Probit model to our cross-sectional online survey data of a sample of 942 responses in 2016, we find that behavioral intention has a significant and positive effect on the choice to purchase energy-saving appliances. Further analysis indicates that environmental attitude and concern, as well as psychological benefits, have significantly positive impacts on respondents' behavioral intention to buy 
energy-saving appliances. Furthermore, age and household size are significantly and positively correlated with the decision to purchase energy-saving appliances.

This study contributes to a thin pile of empirical works of consumer purchasing behavior of energy-saving appliances in China, a country that has the highest greenhouse gas emissions in the world. It does so by integrating environmental concern and psychological benefits with the Theory of Planned Behavior (TPB) and testing the hypotheses based on empirical data from an online survey. In addition to examining the impacts of behavioral intention on the choice to purchase energy-saving appliances, this study attempts to explore the effects of environmental attitudes and concern as well as the influence of psychological benefits on respondents' intention to buy energy-saving devices.

The rest of the paper is organized as follows. We survey existing literature in Section II; outline our methodology, including data connection, theoretical and econometric models in Section III; describe our data in Section IV; discuss the empirical results in Section V; and finally, draw conclusions and policy implications in Section VI.

\section{Theoretical Framework and Hypotheses}

Traditionally, scholars have employed socioeconomic factors to explain consumers' behavior of purchasing energy-efficient household appliances (e.g., Baldini et al., 2018). Furthermore, it is widely believed that intention determines personal behavior in a designed manner, featured most prominently in the Theory of Planned Behavior (TPB) (Ajzen, 1989, 1991). TPB suggests that environmentally-friendly intention involves such mental activities as planning and foresight towards pro-environment behaviors and that attitude plays a vital role in shaping people's behavioral intention to purchase energy-saving appliances (Sapci and Considine, 2014; Cai et al., 
2019). Among the many socioeconomic factors, scholars have zeroed in on age (Zarnikau, 2003; Sardianou and Genoudi, 2013; Baldini et al., 2018), education (Ek, 2005; Tabi et al., 2014), income (Borchers et al., 2007; Grösche and Schröder, 2011; Sardianou and Genoudi, 2013), and household size (Gerpott and Mahmudova, 2010; Grösche and Schröder, 2011; Baldini et al., 2018) to explain purchase behavior.

In addition to the socioeconomic factors, TPB buds off the Theory of Reasoned Action and argues that human behavior is the result of planning and is conditioned by behavioral intention. TPB has been employed widely in social psychology and environmental economics (Fishbein and Ajzen, 1975; Ajzen, 1991; Oreg and Katz-Gerro, 2006). Some studies have applied it to the study of green electricity or renewable energy (see Bang et al., 2000; Litvine and Wüstenhagen, 2011). For example, Mi et al. (2016) demonstrate that residents' behavioral intention prods their behavior in low-carbon energy consumption. Another example is that residents' intention positively influences their behavior in bicycle-sharing commuting in China (Cai et al., 2019). Zhao et al. (2019) suggest that most residents have environmentally friendly intention to buy energy-saving products in Xuzhou, Jiangsu province. Based on these theoretical and empirical insights, we propose our first hypothesis.

Hypothesis 1: Residents' intention has a promotive effect on their choice behavior of purchasing energy-saving appliances.

Furthermore, TPB suggests that personal attitude determines behavioral intention. In the environmental realm, environmental attitude is defined as "the collection of beliefs, affect, and behavioral intentions a person holds regarding environmentally related activities or issues" (Schultz et al., 2004, p.31). Many previous studies have explored how environmental attitudes 
influence the behavioral intention of green consumption (e.g., Paul et al., 2016) or energy savings and carbon reduction (e.g., Chen, 2016). For example, Gadenne et al. (2011) reveal that environmental attitude tends to promote energy-saving behavior in Australia. A puzzle arises: despite much talk about using green, why has the market share of energy-saving appliances remained at 1-3 percent levels of the entire market (Bray, Johns and Kilburn, 2011)? The validity of the theory may be subject to country and cultural contexts, and this may be particularly true for China. Thus, we propose our second hypothesis to test our considerations. Hypothesis 2: Residents' environmental attitude has a positive effect on their intention of purchasing energy-saving appliances.

Recently, a large and growing pipeline of studies indicates that environmental concern is a crucial driver in the adoption of energy-efficient appliances and practices. Schultz et al. (2004) define "environmental concern" as the affect (i.e., worry) associated with beliefs about environmental problems. "Environmental attitude" and "Environmental concern" differ in range, where the former entails a broad general attitude toward the environment while the latter a specific attitude toward environmentally related actions or issues (Fransson and Gärling, 1999). Hansla et al. (2008) suggest that environmental concern affects consumers' willingness to purchase green electricity. Hartmann and Apaolaza-Ibáñez (2012) confirm the finding that consumers' environmental concern facilitates the purchasing intention. Shimokawa and Tezuka (2014) also identify environmental consciousness as a determining factor for the success of the Home 
Energy Conservation Support Program in Japan. Whether environmental concern affects the intention of purchasing energy-saving appliances in China remains an empirical question. Thus, we propose our third hypothesis.

Hypothesis 3: Residents' environmental concern has a positive effect on their intention of purchasing energy-saving appliances.

Besides environmental concern, psychological benefits of purchasing energy-saving appliances can be crucial for individual decision-making (Borchers et al., 2007; Stern, 2011; Sapci and Considine, 2014; Sovacool, 2014; Stern 2014; Noblet et al., 2015). There are two distinct categories of psychological benefits: warm glow and self-expressive benefits. Traditionally, social behavior theory holds that pure altruism contributes to the personal value structure and by extension, induces behavior in favor of the common good (Bergstrom et al., 1986). In contrast, much evidence indicates that some consumers pay a premium price to buy energy-saving appliances for personal welfare derived from a cleaner environment rather than out of altruistic concern, although a cleaner environment is a public good (Wüstenhagen and Bilharze, 2006). This is dubbed the "warm glow of giving" (Andreoni, 1990). Hartmann and Apaolaza-Ibáñez (2012) find that warm glow arising from a contribution to the environment promotes personal behavioral intention to purchase green brands. Thus, we propose our fourth hypothesis.

Hypothesis 4: Warm glow derived from contributing to the environmental common good positively influences the intention to purchase energy-saving appliances.

Another psychological benefit is self-expressiveness of being green, which helps enhance consumers' perceived status and reputation for willingness to contribute to environmental 
protection (Hartmann and Apaolaza-Ibáñez, 2012). Signaling theory and related literature on symbolic and conspicuous consumption offer a basis for our analysis of the impact of self-expressive benefit on the intention (e.g., Aaker, 1999; Bennett and Chakravarti, 2009;

Griskevicius et al., 2010). Because individuals think of and judge others by the products others consume, there could be a real psychological motive and self-expressive benefit for consumers to purchase energy-saving appliances. Although Hartmann and Apaolaza-Ibáñez (2012) do not find self-expressive benefits to be explanatory of participants' purchase intentions, it is a worthwhile empirical question for the context of China. Thus, we propose our fifth hypothesis.

Hypothesis 5: The expectation of self-expressive benefits derived from the conspicuous consumption of energy-saving appliances positively influences the intention to purchase energy-saving appliances.

Based on the analysis mentioned above, our empirical framework for the choice to purchase energy-saving appliances can be summarized in Figure 1.

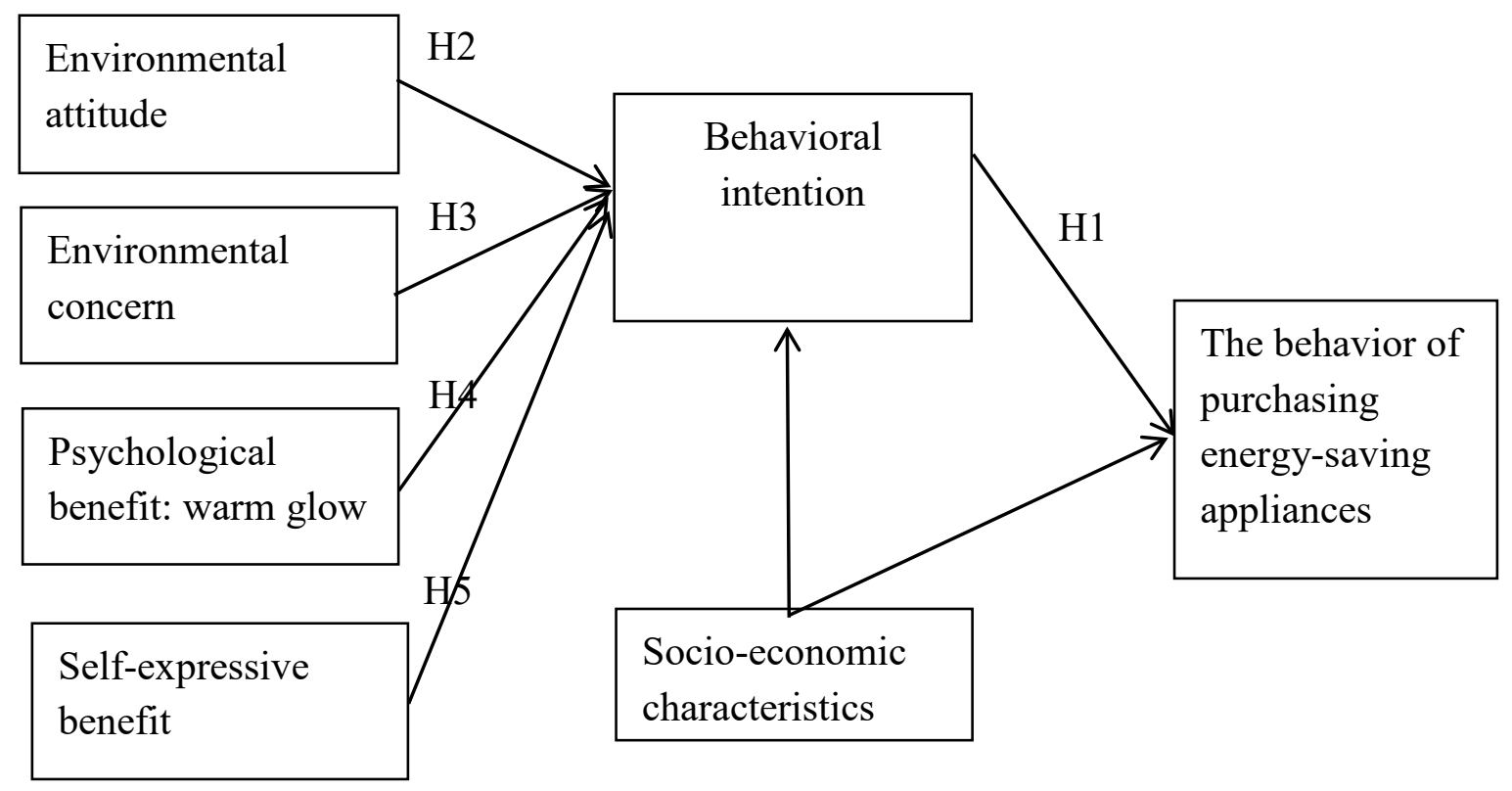

Figure 1. An empirical framework for the choice to purchase energy-saving appliances 


\section{Methodology}

\subsection{Data collection}

We employed Wenjuanxing, a professional marketing agency, to implement our surveys on a secure online platform. ${ }^{3}$ We designed our survey using a modified Dillman method (Dillman et al., 2009). At the initial stage, we organized focus groups to test our pilot survey. Based on the feedback, we refined our survey questionnaire and decided on the final version during the spring of 2016. The respondents were recruited via WeChat, the most popular social media platform in China, with an estimated user base of 0.4 billion at that time. Wenjuanxing company has access to 2.6 million of the 0.4 billion WeChat users and maintains a stable database. The database consisted of urban residents who are little bit more than rural consumers, or 55.6 percent of the Chinese population as of 2015 (CIA World Factbook). Due to the sheer size and diversity of China's population, it is nearly impossible to get a sample representative of the whole population on a limited budget. Urban residents are active thinkers, avid information consumers, and keen experimenters with new things. Since energy-saving appliances are considered relatively new to Chinese consumers, urban residents in China often have more knowledge than rural residents and thus more likely to purchase and benefit from energy saving appliances (Ma et al. 2018).

Therefore, a higher urban representation in our dataset enables us to gather as much as possible

3 The URL of the website is https://www.sojump.com. 
information on how to promote energy-saving appliances. We recognize the cross-country heterogeneity in the urban-rural divide, for example between China (Ma et al. 2018) and India (Parikh and Parikh 2016), and thus limit our interpretations only to what our sample represents."

Respondents were solicited from the database via random sampling, and our dataset is quite representative of urban demographics. Wenjuanxing sent out 1,500 survey requests to its database of WeChat users, among whom 942 completed the survey. The overall response rate is 62.8 percent, which is higher than those in comparable studies on China (Wang et al. 2011). ${ }^{4}$

We excluded residents who did not buy a solar heater if the reason was that they could not access rooftops when living in apartments. We could do this because in our original questionnaire if respondents did not buy any green appliance, we asked them why. If they provided reasons such as they could not access the rooftop, we merely sorted them into the category of "other reasons." Another two potential unbalanced factors in the sample are electric modes of transportation. Electric bikes are currently banned from ten streets in Beijing, and overweight battery cars are prohibited in Shanghai, but neither is forbidden in other localities. On a large scale, the bans have no significant effect on the purchasing of electric bikes for residents. Due to our limited sample size, we do not consider climate variables, such as temperature, in our model - an area where future research can improve.

${ }^{4}$ So far, there is no standard response rate in the literature (Nachmias and Nachmias, 2000). 


\subsection{Measurement of Key Variables}

It is challenging to identify behavioral intention with a subjective question. Following the literature (Biswas and Roy, 2015; Mi et al., 2016), we employ the following question to gauge intention: are you willing to pay more money to buy energy-saving appliances? To obtain a robust measurement, we follow the literature and use the following question as an alternative measure of behavioral intention (e.g., Ajzen, 1991; Litvine and Wüstenhagen, 2011; DeCicco et al., 2015): do you think purchasing energy-saving appliances in the near future will be a good thing?

Following the Theory of Planned Behavior and existing literature (Ajzen, 1991; Sapci and Considine, 2014), we ask the following question to measure environmental attitude: Do you believe that energy is a scarce resource? Alternatively, the question related to environmental attitude can be gauged by: Is your attitude serious toward protecting the environment?

Extending the TPB, we integrate environmental concern into our model. Following the literature (e.g., DeCicco et al., 2015), we raise the following question: do you find it essential to protect the environment? To obtain a robust measurement of environmental concern, following the literature (Hartmann and Apaolaza-Ibáñez, 2012), we also use the following questions as alternative measures: are you concerned about air pollution? Are you worried about climate change?

As for warm glow $(W G)$, the literature (e.g., Hartmann and Apaolaza-Ibáñez, 2012) commonly employs the following question is used as a proxy: by buying energy-saving appliances, do you feel good because you help protect the environment? Alternatively, we use the following question to measure warm glow: by purchasing energy-saving appliances, do you feel that you are contributing to the well-being of humanity and nature? 
Lastly, according to the literature (e.g., Hartmann and Apaolaza-Ibáñez, 2012), we measure self-expressive benefits via the following two questions: does buying energy-saving appliances help express your environmental concern? By buying energy-saving appliances, can you demonstrate to your friends that you care about environmental conservation? All related statements on the measurement of subjective variables: intention, environmental attitude, concern, warm glow, and self-expressive benefit are shown in Table 1.

Table 1 Indicators for measurement of subjective variables: intention, environmental attitude, environmental concern, warm glow, and self-expressive benefit

\begin{tabular}{|c|c|}
\hline Latent variables & Observable measurements \\
\hline $\begin{array}{l}\text { Energy-saving intention } \\
\text { (Int) }\end{array}$ & $\begin{array}{l}\text { Are you willing to pay more money to buy } \\
\text { energy-saving appliances? } \\
\text { Do you think purchasing energy-saving appliances in } \\
\text { the near future will be a good thing? }\end{array}$ \\
\hline Environmental attitude $(E A)$ & $\begin{array}{l}\text { Do you believe that energy is a scarce resource? } \\
\text { Is your attitude serious toward protecting the } \\
\text { environment? }\end{array}$ \\
\hline $\begin{array}{l}\text { Environmental concern } \\
(E C)\end{array}$ & $\begin{array}{l}\text { Do you find it essential to protect the environment? } \\
\text { Are you concerned about air pollution? } \\
\text { Are you worried about climate change? }\end{array}$ \\
\hline Warm glow $(W G)$ & $\begin{array}{l}\text { By buying energy-saving appliances, do you feel good } \\
\text { because you help protect the environment? } \\
\text { By purchasing energy-saving appliances, do you feel } \\
\text { that you are contributing to the well-being of humanity } \\
\text { and nature? }\end{array}$ \\
\hline $\begin{array}{l}\text { Self-expressive benefit } \\
(S E B)\end{array}$ & $\begin{array}{l}\text { Does buying energy-saving appliances help express } \\
\text { your environmental concern? } \\
\text { By buying energy-saving appliances, can you } \\
\text { demonstrate to your friends that you care about } \\
\text { environmental conservation? }\end{array}$ \\
\hline
\end{tabular}

\subsection{Empirical model}

We built our empirical model by drawing from and modifying insights from the following 
theories. First, a rational consumer maximizes her utility subject to her budget, and as the price of the commodity increases, her demand for it decreases. Second, an increase in income leads to higher demand according to the permanent income hypothesis (Friedman, 1957). Third, consumption is determined by consumer's preferences. However, the same principle of consumer's preferences needs to be adapted to fit a more complicated situation of buying energy-saving appliances. Of particular note, if respondents realize that the economic benefits of such energy efficiency measures as efficient lighting system in the household sector manifest in the long term (Baldini and Trivella, 2018), they will become more likely to purchase the new energy-efficient lighting system.

In the context of energy-saving behavior, the utility theory provides the basis for interpreting dominance in pairwise selection (McFadden, 1974). Since utilities for goods or services can be categorized based on their characteristics or attributes (Lancaster, 1966), the relationship between choice decision behaviors and driving forces can be expressed as linear. In this specification, a dummy model is applied to our case of purchasing energy-saving appliances (Heckman, 1979), and our final econometric model is as follows:

$$
\operatorname{logit}(\operatorname{Pr}(E S A=1))=\alpha+\beta I n t+\gamma_{1} A g e+\gamma_{2} E d u+\gamma_{3} I n c+\gamma_{4} H S+\varepsilon
$$
where $E S A$ is the stated choice to buy energy-saving appliances, which is binary, in the case 1 (decision to buy energy-saving appliances), otherwise 0 (decision not to buy energy-saving appliances); $\alpha$ is constant; $\beta$ is the coefficient for respondents' intention to purchase energy-saving appliances $(\operatorname{Int}) ; \gamma$ is the coefficients vector for respondents' socioeconomic characteristics, including age (Age), education (Edu), income (Inc), and household size (HS); $\varepsilon$ is the error term, which is assumed to be i.i.d.

Since the independent variable, the choice to purchase energy-saving appliances (ESA) is 
binary, the appropriate probabilistic choice models are logit and probit models. Although Logit and Probit are used to perform a similar type of regression, they employ different functions. Given the relatively large size of our sample, we employed a Probit model in this study.

As mentioned above, environmental attitude $(E A)$, environmental concern $(E C)$, warm glow $(W G)$, and self-expressive benefit ( $S E B$ ) might influence the intention to purchase energy-saving appliances. This study further investigates their effects on the intention and subsequently, energy-saving purchasing behavior. We also include socioeconomic variables (age, education, income, and household size) as the control variables. Mathematically, it can be expressed as:

$$
\operatorname{logit}(\operatorname{Pr}(\operatorname{Int}=1))=\alpha+\phi E A+\lambda E C+\psi W G+\xi S E B+\gamma_{1} A g e+\gamma_{2} E d u+\gamma_{3} I n c+\gamma_{4} H S+\mu
$$

where $\mu$ represents the error term, assumed to be i.i.d. The independent variable, behavioral intention ( Int ), is measured via two questions. The willingness question involves a binary variable, so a Probit model is employed. In the second question, "good thing" is an ordered choice variable, so an ordered Probit model is applied.

\section{Survey Results}

Based on our literature review (e.g., Chen and Chai, 2010; Hartmann and Apaolaza-Ibáñez, 2012; Stern 2014; Sapci and Considine, 2014; Noblet et al., 2015), we create a questionnaire that consists of two areas. The items and the results are reported in Table 2-3, respectively.

The first set of seven questions (Q1 - Q8a) is related to the respondents' demographic and socioeconomic characteristics (age, educational attainment, household income, and household size), household monthly electricity consumption, purchasing decision (whether or not the respondent has purchased energy-saving appliances), the amount spent on energy-efficiency home appliances, and willingness to pay more money to buy energy-saving appliances. The 
summary statistics are presented in Table 2.

Table 2. Demographic and household characteristics of respondents (Q1-Q7)

\begin{tabular}{|c|c|c|c|c|c|c|}
\hline Socio-economic features & Definition and unit & Average & S.d. & Min. & Max. & $\begin{array}{l}\text { National } \\
\text { average }\end{array}$ \\
\hline Q1 Age & Mean, years & 34.3 & 9.6 & 21.5 & 65.0 & 36.0 \\
\hline Q2 Education (Edu) & Education years & 17.5 & 2.9 & 9.0 & 22.0 & 10.1 \\
\hline Q3 Income (Inc) & $\begin{array}{l}\text { Annual income, } 1000 \\
\mathrm{RMB}\end{array}$ & 144.0 & 105.0 & 25.0 & 350.0 & 134.0 \\
\hline Q4 Household size (HS) & $\begin{array}{l}\text { Household size, } \\
\text { number of people }\end{array}$ & 3.9 & 1.3 & 1.0 & 6.0 & 3.1 \\
\hline $\begin{array}{l}\text { Q5 Electricity } \\
\text { consumption (Elec) }\end{array}$ & $\begin{array}{l}\text { Electricity } \\
\text { consumption, } \mathrm{kW} / \mathrm{h} \\
\text { per month } \square\end{array}$ & 105.5 & 62.1 & 25.0 & 250.0 & 110.0 \\
\hline $\begin{array}{l}\text { Q6 Choice to buy } \\
\text { energy-saving appliances }\end{array}$ & Percentage & 0.70 & 0.46 & 0.00 & 1.00 & \\
\hline $\begin{array}{l}\text { Q7 The amount spent on } \\
\text { energy-efficiency home } \\
\text { appliances }\end{array}$ & $\begin{array}{l}1000 \text { RMB per } \\
\text { household }\end{array}$ & 10.21 & 34.58 & 0.0 & 633.0 & \\
\hline $\begin{array}{l}\text { Q8a Are you willing to } \\
\text { pay more money to buy } \\
\text { energy-saving } \\
\text { appliances? }(\operatorname{Int}(1))\end{array}$ & $\begin{array}{l}\text { Dummy variable } \\
\text { Yes }=1 \text {, otherwise, } 0\end{array}$ & 0.85 & 0.36 & 0.00 & 1.00 & \\
\hline
\end{tabular}

Note: data on the national average were taken from Chinese Statistical Yearbooks.

The survey shows that more than 70 percent of respondents made decisions on the choice of purchasing energy-efficient home appliances, and the amount spent on energy-efficiency home appliances per household was, on average, 10205.8 Chinese Yuan (US\$1458). Q8a uses “Are you willing to pay more money to buy energy-saving appliances? (Int(1))" to measure environmental intention. Regarding the percentage of willingness to pay more for energy-saving appliances, 85 percent of respondents indicated willingness to pay price premium for energy-saving appliances, which is much higher than an average of 30 percent in Brunei and 44-50 percent in Europe (Shi, 2015). A comprehensive review of the amount of willingness to pay can be found in Shi (2014). Our finding on the price premium is consistent with that in Zeng et al. (2014), which shows that Chinese consumers on average are only willing to spend less than 
10 percent of price premium. The price premium in China, however, is much lower than that in European and North American (Zarnikau, 2003; Eurobarometer, 2005; Kaenzig et al., 2013). Bear in mind, it is difficult to identify the heterogenous impact across regions because respondent are largely concentrated in the coastal cities. They are urbanites in relatively developed regions whose preferences are likely similar.

We also inquired: why don't you choose to buy green energy-efficient appliance? Among the 58.6 percent of the responses that specified reasons, the most common reason was the higher price of green products compared to conventional products (29.1 percent), followed by insufficient information about green products (21.1 percent), unreliable quality of green products (20.0 percent), and unreliable certification of green electricity product (16.5 percent).

We further investigated the questions related to respondents' degree of trust in green appliance labeling certifications. 29.6 percent of respondents stated trust ( 8.8 percent completely trust and 20.8 percent trust) in China's environmental labeling certification. The percentages are 34.6 for China's energy efficiency certification and 31.8 percent for China's energy-saving product certification. Since we focus on energy-saving behavior of respondents in this study, we save these interesting statistics for a different study.

Table 3 presents summary statistics of responses related to behavioral intention, environmental attitude, environmental concern, and psychological benefits (warm glow and self-expressive benefit) (Q8b-Q12) with a traditional 5-point scale measuring the likelihood that participants would consider "Strongly disagree," "Disagree," "Neutral," "Agree," and "Strongly agree" (Hartmann and Apaolaza-Ibáñez, 2012). According to the measurement description in Section 3.2, we use two indicators to measure environmental intention (Int). Alternatively, Q8b uses “do you think purchasing energy-saving appliances in the near future 
will be a good thing $(\operatorname{int}(2))$ )" to measure the environmental intention. 86.2 percent of respondents agree (37.4 percent agree and 48.8 percent strongly agree) that purchasing energy-saving appliances in the near future will be a good thing. $\square$

Table 3. Descriptive statistics of environmental attitude, concern and psychological benefits (\%)

\begin{tabular}{|c|c|c|c|c|c|}
\hline & $\begin{array}{l}\text { Strongly } \\
\text { disagree }\end{array}$ & Disagree & Neutral & Agree & $\begin{array}{l}\text { Strongly } \\
\text { agree }\end{array}$ \\
\hline \multicolumn{6}{|l|}{ Q8b Intention (Int) } \\
\hline $\begin{array}{l}\text { Do you think in the near future } \\
\text { purchasing green products will be a } \\
\text { good thing? } \square(\operatorname{Int}(2))\end{array}$ & 2.0 & 2.3 & 9.4 & 37.4 & 48.8 \\
\hline \multicolumn{6}{|l|}{ Q9 Environmental attitude } \\
\hline $\begin{array}{l}\text { a. Do you believe that energy is a } \\
\text { scarce resource? }\end{array}$ & 3.1 & 4.5 & 13.0 & 32.8 & 46.7 \\
\hline $\begin{array}{l}\text { b. Is your attitude serious toward } \\
\text { protecting the environment? }\end{array}$ & 1.7 & 2.3 & 9.0 & 34.3 & 52.7 \\
\hline \multicolumn{6}{|l|}{ Q10 Environmental concern } \\
\hline $\begin{array}{l}\text { a. Do you realize it is important to } \\
\text { protect the environment? }\end{array}$ & 1.7 & 1.4 & 6.6 & 22.1 & 68.3 \\
\hline $\begin{array}{l}\text { b. Are you concern about air } \\
\text { pollution? }\end{array}$ & 1.8 & 1.3 & 6.5 & 22.7 & 67.7 \\
\hline $\begin{array}{l}\text { a. Are you concern about climate } \\
\text { change? }\end{array}$ & 1.9 & 2.0 & 10.9 & 35.7 & 49.5 \\
\hline \multicolumn{6}{|l|}{ Q11 Warm glow } \\
\hline $\begin{array}{l}\text { a. By buying energy-saving } \\
\text { appliances, do you feel good because } \\
\text { you help to protect the environment? }\end{array}$ & 4.2 & 7.1 & 25.7 & 40.3 & 22.6 \\
\hline $\begin{array}{l}\text { b. By buying energy-saving } \\
\text { appliances, do you feel that you are } \\
\text { contributing to the well-being of } \\
\text { humanity and nature? }\end{array}$ & 11.1 & 14.6 & 30.9 & 28.3 & 15.0 \\
\hline \multicolumn{6}{|l|}{ Q12 Self-expressive benefit } \\
\hline $\begin{array}{l}\text { a. By buying energy-saving } \\
\text { appliances, can you express your } \\
\text { environmental concern? }\end{array}$ & 6.9 & 11.1 & 25.8 & 37.5 & 18.7 \\
\hline $\begin{array}{l}\text { b. By buying energy-saving } \\
\text { appliances, can you demonstrate to } \\
\text { your friends that you care about } \\
\text { environmental conservation? }\end{array}$ & 4.7 & 8.2 & 24.1 & 40.2 & 22.8 \\
\hline Average & 3.91 & 5.48 & 16.19 & 33.13 & 41.28 \\
\hline
\end{tabular}


Regarding environmental attitude, 79.5 percent (32.8 percent agree, and 46.7 percent strongly agree) of respondents believe that energy is a scarce resource and 89 percent (34.3 percent agree and 52.7 percent strongly agree) of respondents' attitude towards protecting the environment are serious as well. As for environmental concern, 90.4 percent (22.1 percent agree and 68.3 percent strongly agree) of respondents realize that it is important to protect the environment, which is consistent with prior research (Ellen et al., 2006; Vermeir and Verbeke, 2006; Arvola et al., 2008; Liu et al., 2012). Similarly, 90.4 percent of respondents (22.7 percent agree and 67.7 percent strongly agree) are concerned about air pollution, and 85.2 percent (35.7 percent agree, and 49.5 percent strongly agree) are about climate change.

Regarding psychological benefits, 62.9 percent of respondents (40.3 percent agree and 22.6 percent strongly agree) feel good because they help to protect the environment by buying energy-saving appliances. A bit surprisingly, less than 50 percent of respondents (28.3 percent agree, and 15.0 percent strongly agree) feel that they contribute to the well-being of humanity and nature by buying energy-saving appliances. Likewise, 56.2 percent of respondents (37.5 percent agree, and 18.7 percent strongly agree) express their environmental concern by buying energy-saving appliances, and 63.5 percent of respondents (40.2 percent agree, and 22.8 percent strongly agree) demonstrate to their friends that they care about environmental conservation by buying energy-saving appliances. On average, 74.4 percent of respondents appear to be pro-environment (33.13 percent agree and 41.28 percent strongly agree).

\section{Econometric Analysis}

Before carrying out empirical analyses, we checked the multicollinearity among the explanatory variables using Pearson and Spearman methods. The results show that the 
correlation coefficients among all explanatory variables are less than 0.56 , so we moved ahead to conduct econometric analyses. $^{5}$

\subsection{Behavioral Intention and the Choice to Purchase Energy-Saving Appliances}

Table 4 presents the Probit regression results of the impacts of behavioral intention on respondents' choice to purchase energy-saving appliances. Because the two questions associated with behavioral intention are highly correlated with each other, following the literature (Sapci and Considine, 2014), each of our regressions includes only one intention question at a time. Additionally, we perform analysis both with and without control variables (household characteristics). If the sign and magnitude of the key variable (intention) in model 1 are still similar to those from model 2, we can conclude that the findings are robust. Employing different control variables is a common practice in the literature to test the robustness of results (Wooldrige, p461, 2001). The results show that intention question $1(\operatorname{Int}(1))$ has a consistently significant and positive effect on the choice to purchase energy-saving appliances, with or without household features included (Model 1 and 2). This finding is in line with the literature (Biswas and Roy, 2015; Mi et al., 2016; Cai et al., 2019), indicating that people who are willing to buy also translate their choice into action.

Likewise, the results also show that intention Q8b (Int (2)) has consistently significant and positive effect on the choice to purchase energy-saving appliances, with or without household

5 Due to space constraints, we do not report our test results, but they will be available from the authors upon request. 
features (Models 3 and 4), and this is consistent with several studies in the literature (e.g. Hartmann and Apaolaza-Ibáñez, 2012; DeCicco et al., 2015). The two findings demonstrate that environmentally friendly behavior first requires behavioral intention, underpinned by the actors' knowing that their potential acts to improve environmental quality may have consequences for the welfare of others. Hypothesis (H1) is supported.

Regarding demographic characteristics, age and household size are both significantly and positively related to buying energy-saving appliances, which agrees with the literature (Grösche and Schröder, 2011; Sardianou and Genoudi, 2013). The explanation is straightforward: as respondents grow old, they become more concerned about the environment and more likely to purchase energy-saving appliances to save energy. Likewise, as the household size gets larger, respondents recognize that purchasing energy-saving devices can save more energy and reduce their expenditure in the long term. Education and income have expectedly signs; however, they are insignificant factors in the case of China, different from the prevailing evidence from developed countries. We identify some potential rationale from a few extant works that may suggest that our finding for China is not unique. For instance, Long et al. (2018) find that education beyond high school is no longer a significant explanatory factor for buying energy-efficient appliances in Germany and the USA. Baldini et al. (2018) indicate that income is a weak predictor, even among the well-educated in Denmark. Abrahamse and Steg (2009) also suggest that household energy savings appear not to be associated with socio-demographics in the case of the Netherlands. 
Table 4. Impacts of behavioral intention on respondents' choice to purchase energy-saving appliances $(E S A)$ in China with Probit model (Buy=1, otherwise, 0)

\begin{tabular}{|c|c|c|c|c|}
\hline Variables & $\begin{array}{l}\text { Model } 1 \\
\text { Probit }\end{array}$ & $\begin{array}{l}\text { Model } 2 \\
\text { Probit }\end{array}$ & $\begin{array}{l}\text { Model } 3 \\
\text { Probit }\end{array}$ & $\begin{array}{l}\text { Model } 4 \\
\text { probit }\end{array}$ \\
\hline \multicolumn{5}{|l|}{ Energy-saving intention (Int): } \\
\hline $\begin{array}{l}\text { Are you willing to pay more money to } \\
\text { buy energy-saving appliances? }\end{array}$ & $\begin{array}{l}0.329^{* * *} \\
(0.101)\end{array}$ & $\begin{array}{l}0.322^{* * *} \\
(0.104)\end{array}$ & & \\
\hline $\begin{array}{l}\text { Do you think in the near future } \\
\text { purchasing energy-saving appliances will } \\
\text { be a good thing? }\end{array}$ & & & $\begin{array}{l}0.255^{* * *} \\
(0.048)\end{array}$ & $\begin{array}{l}0.247^{* * *} \\
(0.049)\end{array}$ \\
\hline \multicolumn{5}{|l|}{ Socio-demographics } \\
\hline Age & & $\begin{array}{l}0.666^{* * *} \\
(0.162)\end{array}$ & & $\begin{array}{l}0.661^{* * *} \\
(0.163)\end{array}$ \\
\hline Education & & $\begin{array}{l}0.027 \\
(0.205)\end{array}$ & & $\begin{array}{l}0.065 \\
(0.051)\end{array}$ \\
\hline Income & & $\begin{array}{l}0.073 \\
(0.051)\end{array}$ & & $\begin{array}{l}0.054 \\
(0.205)\end{array}$ \\
\hline Household size & & $\begin{array}{l}0.255^{* *} \\
(0.107)\end{array}$ & & $\begin{array}{l}0.248^{* *} \\
(0.108)\end{array}$ \\
\hline Constant & $\begin{array}{l}0.227^{* * *} \\
(0.098)\end{array}$ & $\begin{array}{l}-2.656^{* * *} \\
(0.797)\end{array}$ & $\begin{array}{l}-0.567^{* * *} \\
(0.207)\end{array}$ & $\begin{array}{l}-3.455^{* * *} \\
(0.826)\end{array}$ \\
\hline Obs. & 942 & 942 & 942 & 942 \\
\hline Prob $>$ chi2 & 0.000 & 0.000 & 0.000 & 0.000 \\
\hline
\end{tabular}

\subsection{Effects of Environmental Attitude and Concern and Psychological Benefits on}

\section{Behavioral Intention}

Table 5 displays the probit regressions results of the effects of environmental attitude and concern as well as psychological benefits on respondents' behavioral intention to purchase energy-saving appliances (willingness to pay: Int(1)). The results of models (5) - (6) in Table 5 reveal that environmental attitude has significantly positive effects on respondents' intention to purchase energy-saving appliances across different specifications. We note that the sign for age is negative in model 6 , but positive in model 5 . A possible explanation is that the measurement 
for the key variable, environmental attitude, is different (a vs. b). Since it is correlated with age ( 0.001 for a and 0.081 for b by Spearman test, respectively), it influences the sign and magnitude of age. Interestingly, age in both model 5 and 6 are statistically insignificant with different signs, suggesting that the correlation between the key variables and age are trivial and can be ignored (Wooldridge, p78, 2001).

Environmental concern and environmental attitude have similar effects on the intention to purchase energy-saving appliances. The results of models (7)-(9) in Table 5 demonstrate that environmental concern also has significant positive effects on respondents' intention to purchase energy-saving appliances.

As expected, the findings confirm the positive influence of consumers' environmental attitude and concern on purchase intention presented in our theoretical and hypothetical section and are in line with the existing literature (e.g., Gadenne et al., 2011; Chen, 2016; Paul et al., 2016). Thus, our hypotheses (H2 and H3) are supported.

Warm glow is found to be a statistically significant explanatory variable in models (10)-(11) of Table 5, indicating that warm glow is a primary driver of variation in the outcomes and that consumers' expectation of personal psychological happiness potentially motivates her intention to purchase energy-saving appliances. Unlike altruism, consumers pursuing their own psychological happiness contributes to environmental protection (Hartmann and Apaolaza-Ibáñez, 2012). The findings support our hypotheses and are in line with the existing literature (e.g., Hartmann and Apaolaza-Ibáñez, 2012).

Lastly, the results of estimating the effects of self-expressive benefit in models (12)-(13) in Table 5 show a positive influence on the intention to purchase energy-saving appliances. The findings confirm our statement in the theoretical and hypothetical section in this study and are 
line with some previous studies (e.g., Griskevicius et al., 2010), although Hartmann and Apaolaza-Ibáñez (2012) does not find a significant relationship between self-expressive benefit and purchase intention. Thus, our hypotheses (H4 and H5) are supported.

As to the importance of the magnitude of the estimates, the findings demonstrate that Warm glow "By buying energy-saving appliances, do you feel good because you help to protect the environment?" with the coefficient by 0.368 has relatively larger impact than other variables in Table 5.

Unexpectedly, all the control variables except income, are not significant. Income turns out to have significantly positive impacts on the intention to purchase energy-saving appliances. According to the permanent income hypothesis, as income increases, respondents become more inclined to buy energy-saving devices.

\subsection{Robustness Check}

Previous studies have employed different indicators as alternative measures to conduct robustness checks. In contrast to the regressions in Table 5, regressions in Table 6 employ "Do you think purchasing green products in the near future will be a good thing?" as an alternative measure of environmental intention. If the sign and magnitude of the key variable in Table 6 are still similar to Table 5, the results are robust. 
Table 5. Impacts of environmental attitude, concern and psychological benefits on behavioral intention, represented by the willingness to pay for energy-saving appliances (Int (1))

\begin{tabular}{lllcll}
\hline Variables & $\begin{array}{l}\text { Model 5 } \\
\text { probit }\end{array}$ & $\begin{array}{l}\text { Model 6 } \\
\text { probit }\end{array}$ & $\begin{array}{c}\text { Model 7 } \\
\text { probit }\end{array}$ & $\begin{array}{l}\text { Model 8 } \\
\text { probit }\end{array}$ & $\begin{array}{l}\text { Model 9 } \\
\text { probit }\end{array}$
\end{tabular}

Environmental attitude

Do you believe that energy is a $\quad 0.179^{* * *}$

scarce resource?

(0.046)

Is your attitude toward protecting the environment serious?

$0.171^{* * *}$

$(0.054)$

Environmental concern

Do you realize it is important to protect the environment?

Are you concern about air pollution?

$$
\begin{aligned}
& 0.162^{* * *} \\
& (0.056)
\end{aligned}
$$

Are you concern about climate change?

\begin{tabular}{|c|c|c|c|c|c|}
\hline Age & $\begin{array}{l}0.038 \\
(0.184)\end{array}$ & $\begin{array}{l}-0.018 \\
(0.184)\end{array}$ & $\begin{array}{l}-0.022 \\
(0.184)\end{array}$ & $\begin{array}{l}-0.022 \\
(0.184)\end{array}$ & $\begin{array}{l}-0.042 \\
(0.185)\end{array}$ \\
\hline Education & $\begin{array}{l}0.117 \\
(0.245)\end{array}$ & $\begin{array}{l}0.109 \\
(0.243)\end{array}$ & $\begin{array}{l}0.110 \\
(0.244)\end{array}$ & $\begin{array}{l}0.105 \\
(0.244)\end{array}$ & $\begin{array}{l}0.084 \\
(0.244)\end{array}$ \\
\hline Income & $\begin{array}{l}0.139^{* *} \\
(0.058)\end{array}$ & $\begin{array}{l}0.149^{* * *} \\
(0.057)\end{array}$ & $\begin{array}{l}0.147^{* * *} \\
(0.057)\end{array}$ & $\begin{array}{l}0.151^{* * *} \\
(0.057)\end{array}$ & $\begin{array}{l}0.155^{* * *} \\
(0.057)\end{array}$ \\
\hline Household size & $\begin{array}{l}-0.002 \\
(0.126)\end{array}$ & $\begin{array}{l}-0.021 \\
(0.125)\end{array}$ & $\begin{array}{l}-0.012 \\
(0.125)\end{array}$ & $\begin{array}{l}-0.007 \\
(0.124)\end{array}$ & $\begin{array}{l}-0.020 \\
(0.125)\end{array}$ \\
\hline Constant & $\begin{array}{l}-0.471 \\
(0.955)\end{array}$ & $\begin{array}{l}-0.257 \\
(0.946)\end{array}$ & $\begin{array}{l}-0.243 \\
(0.952)\end{array}$ & $\begin{array}{l}0.015 \\
(0.947)\end{array}$ & $\begin{array}{l}-0.057 \\
(0.937)\end{array}$ \\
\hline Obs. & 942 & 942 & 942 & 942 & 942 \\
\hline Prob $>$ chi2 & 0.000 & 0.000 & 0.000 & 0.000 & 0.000 \\
\hline
\end{tabular}

\section{Socio-demographics}

Notes: Numbers in parentheses are standard errors. ${ }^{* * *},{ }^{* *}$ and ${ }^{*}$ indicate the levels of statistical significance at 1 percent, 5 percent, and 10 percent, respectively. 
Table 5b. Continued:

\begin{tabular}{|c|c|c|c|c|}
\hline Variables & $\begin{array}{l}\text { Model } 10 \\
\text { probit }\end{array}$ & $\begin{array}{l}\text { Model } 11 \\
\text { probit }\end{array}$ & $\begin{array}{l}\text { Model } 12 \\
\text { probit }\end{array}$ & $\begin{array}{l}\text { Model } 13 \\
\text { probit }\end{array}$ \\
\hline \multicolumn{5}{|l|}{ Warm glow } \\
\hline $\begin{array}{l}\text { By buying energy-saving appliances, } \\
\text { do you feel good because you help to } \\
\text { protect the environment? }\end{array}$ & $\begin{array}{l}0.368^{* * *} \\
(0.048)\end{array}$ & & & \\
\hline $\begin{array}{l}\text { By buying energy-saving appliances, } \\
\text { do you feel that you are contributing to } \\
\text { the well-being of humanity and nature? }\end{array}$ & & $\begin{array}{l}0.302^{* * *} \\
(0.047)\end{array}$ & & \\
\hline \multicolumn{5}{|l|}{ Self-expressive benefits } \\
\hline $\begin{array}{l}\text { By buying energy-saving appliances, } \\
\text { can you express your environmental } \\
\text { concern? }\end{array}$ & & & $\begin{array}{l}0.238^{* * *} \\
(0.044)\end{array}$ & \\
\hline $\begin{array}{l}\text { By buying energy-saving appliances, } \\
\text { can you demonstrate to your friends } \\
\text { that you care about environmental } \\
\text { conservation? }\end{array}$ & & & & $\begin{array}{l}0.183^{* * *} \\
(0.042)\end{array}$ \\
\hline \multicolumn{5}{|l|}{ Socio-demographics } \\
\hline Age & $\begin{array}{l}-0.037 \\
(0.189)\end{array}$ & $\begin{array}{l}-0.086 \\
(0.188)\end{array}$ & $\begin{array}{l}-0.007 \\
(0.186)\end{array}$ & $\begin{array}{l}0.039 \\
(0.185)\end{array}$ \\
\hline Education & $\begin{array}{l}0.209 \\
(0.253)\end{array}$ & $\begin{array}{l}0.171 \\
(0.249)\end{array}$ & $\begin{array}{l}0.149 \\
(0.249)\end{array}$ & $\begin{array}{l}0.146 \\
(0.248)\end{array}$ \\
\hline Income & $\begin{array}{l}0.157^{* * *} \\
(0.059)\end{array}$ & $\begin{array}{l}0.176^{* * *} \\
(0.058)\end{array}$ & $\begin{array}{l}0.173^{* * *} \\
(0.058)\end{array}$ & $\begin{array}{l}0.168^{* * *} \\
(0.058)\end{array}$ \\
\hline Household size & $\begin{array}{l}-0.054 \\
(0.129)\end{array}$ & $\begin{array}{l}-0.032 \\
(0.127)\end{array}$ & $\begin{array}{l}-0.060 \\
(0.127)\end{array}$ & $\begin{array}{l}-0.027 \\
(0.126)\end{array}$ \\
\hline Constant & $\begin{array}{l}-1.008 \\
(0.971)\end{array}$ & $\begin{array}{l}-0.570 \\
(0.957)\end{array}$ & $\begin{array}{l}-0.478 \\
(0.948)\end{array}$ & $\begin{array}{l}-0.429 \\
(0.951)\end{array}$ \\
\hline Obs. & 942 & 942 & 942 & 942 \\
\hline Prob $>$ chi 2 & 0.000 & 0.000 & 0.000 & 0.000 \\
\hline
\end{tabular}

Notes: Numbers in parentheses are standard errors. ${ }^{* * *},{ }^{* *}$ and ${ }^{*}$ indicate the levels of statistical significance at 1 percent, 5 percent, and 10 percent, respectively.

Table 6 presents the ordered probit regression results of the effects of environmental attitude and concern as well as psychological benefits on respondents' behavioral intention 
(Int(2)) to purchase energy-saving appliances in China.

Table 6. Robust check: Impacts of environmental attitude, concern and psychological benefits on behavioral intention of purchasing energy-saving appliances (Int (2))

\begin{tabular}{|c|c|c|c|c|c|}
\hline Variables & $\begin{array}{l}\text { Model } 14 \\
\text { Ordered } \\
\text { probit }\end{array}$ & $\begin{array}{l}\text { Model } 15 \\
\text { Ordered } \\
\text { probit }\end{array}$ & $\begin{array}{l}\text { Model } 16 \\
\text { Ordered } \\
\text { probit }\end{array}$ & $\begin{array}{l}\text { Model } \\
17 \\
\text { Ordered } \\
\text { probit }\end{array}$ & $\begin{array}{l}\text { Model } 18 \\
\text { Ordered } \\
\text { probit }\end{array}$ \\
\hline \multicolumn{6}{|l|}{ Environmental attitude } \\
\hline $\begin{array}{l}\text { Do you believe that energy is a } \\
\text { scarce resource? }\end{array}$ & $\begin{array}{l}0.523^{* * *} \\
(0.038)\end{array}$ & & & & \\
\hline $\begin{array}{l}\text { Is your attitude toward } \\
\text { protecting the environment } \\
\text { serious? }\end{array}$ & & $\begin{array}{l}0.836^{* * *} \\
(0.048)\end{array}$ & & & \\
\hline \multicolumn{6}{|l|}{ Environmental concern } \\
\hline $\begin{array}{l}\text { Do you realize it is important to } \\
\text { protect the environment? }\end{array}$ & & & $\begin{array}{l}0.838^{* * *} \\
(0.050)\end{array}$ & & \\
\hline $\begin{array}{l}\text { Are you concern about air } \\
\text { pollution? }\end{array}$ & & & & $\begin{array}{l}0.740^{* * *} \\
(0.049)\end{array}$ & \\
\hline $\begin{array}{l}\text { Are you concern about climate } \\
\text { change? }\end{array}$ & & & & & $\begin{array}{l}0.731^{* * *} \\
(0.046)\end{array}$ \\
\hline \multicolumn{6}{|l|}{ Socio-demographics } \\
\hline Age & $\begin{array}{l}0.194 \\
(0.141)\end{array}$ & $\begin{array}{l}-0.046 \\
(0.144)\end{array}$ & $\begin{array}{l}-0.074 \\
(0.143)\end{array}$ & $\begin{array}{l}-0.132 \\
(0.142)\end{array}$ & $\begin{array}{l}-0.145 \\
(0.143)\end{array}$ \\
\hline Education & $\begin{array}{l}-0.170 \\
(0.178)\end{array}$ & $\begin{array}{l}-0.166 \\
(0.180)\end{array}$ & $\begin{array}{l}-0.138 \\
(0.179)\end{array}$ & $\begin{array}{l}-0.156 \\
(0.178)\end{array}$ & $\begin{array}{l}-0.310 \\
(0.180)\end{array}$ \\
\hline Income & $\begin{array}{l}0.035 \\
(0.044)\end{array}$ & $\begin{array}{l}0.067 \\
(0.045)\end{array}$ & $\begin{array}{l}0.058 \\
(0.045)\end{array}$ & $\begin{array}{l}0.050 \\
(0.044)\end{array}$ & $\begin{array}{l}0.087^{* *} \\
(0.044)\end{array}$ \\
\hline Household size & $\begin{array}{l}0.082 \\
(0.094)\end{array}$ & $\begin{array}{l}0.008 \\
(0.096)\end{array}$ & $\begin{array}{l}0.033 \\
(0.095)\end{array}$ & $\begin{array}{l}0.054 \\
(0.094)\end{array}$ & $\begin{array}{l}0.004 \\
(0.095)\end{array}$ \\
\hline Obs. & 942 & 942 & 942 & 942 & 942 \\
\hline Prob $>$ chi2 & 0.000 & 0.000 & 0.000 & 0.000 & 0.000 \\
\hline
\end{tabular}

Notes: Numbers in parentheses are standard errors. ${ }^{* * *},{ }^{* *}$ and ${ }^{*}$ indicate the levels of statistical significance at 1 percent, 5 percent, and 10 percent, respectively. 
Table 6. Continued:

\begin{tabular}{|c|c|c|c|c|}
\hline Variables & $\begin{array}{l}\text { Model } 19 \\
\text { Ordered } \\
\text { probit }\end{array}$ & $\begin{array}{l}\text { Model } 20 \\
\text { Ordered } \\
\text { probit }\end{array}$ & $\begin{array}{l}\text { Model } 21 \\
\text { Ordered } \\
\text { probit }\end{array}$ & $\begin{array}{l}\text { Model 22 } \\
\text { Ordered } \\
\text { probit }\end{array}$ \\
\hline \multicolumn{5}{|l|}{ Warm glow } \\
\hline $\begin{array}{l}\text { By buying energy-saving } \\
\text { appliances, do you feel good } \\
\text { because you help to protect the } \\
\text { environment? }\end{array}$ & $\begin{array}{l}0.611^{* * *} \\
(0.040)\end{array}$ & & & \\
\hline $\begin{array}{l}\text { By buying energy-saving } \\
\text { appliances, do you feel that you } \\
\text { are contributing to the well-being } \\
\text { of humanity and nature? }\end{array}$ & & $\begin{array}{l}0.629^{* * *} \\
(0.039)\end{array}$ & & \\
\hline \multicolumn{5}{|l|}{ Self-expressive benefits } \\
\hline $\begin{array}{l}\text { By buying energy-saving } \\
\text { appliances, can you express your } \\
\text { environmental concern? }\end{array}$ & & & $\begin{array}{l}0.485^{* * *} \\
(0.036)\end{array}$ & \\
\hline $\begin{array}{l}\text { By buying energy-saving } \\
\text { appliances, can you demonstrate } \\
\text { to your friends that you care about } \\
\text { environmental conservation? }\end{array}$ & & & & $\begin{array}{l}0.305^{* * *} \\
(0.033)\end{array}$ \\
\hline \multicolumn{5}{|l|}{ Socio-demographics } \\
\hline Age & $\begin{array}{l}-0.009 \\
(0.142)\end{array}$ & $\begin{array}{l}-0.071 \\
(0.143)\end{array}$ & $\begin{array}{l}0.066 \\
(0.178)\end{array}$ & $\begin{array}{l}0.159 \\
(0.140)\end{array}$ \\
\hline Education & $\begin{array}{l}-0.094 \\
(0.179)\end{array}$ & $\begin{array}{l}-0.091 \\
(0.179)\end{array}$ & $\begin{array}{l}-0.129 \\
(0.053)\end{array}$ & $\begin{array}{l}-0.151 \\
(0.175)\end{array}$ \\
\hline Income & $\begin{array}{l}0.079^{* *} \\
(0.044)\end{array}$ & $\begin{array}{l}0.115^{* * *} \\
(0.045)\end{array}$ & $\begin{array}{l}0.108^{* * *} \\
(0.044)\end{array}$ & $\begin{array}{l}0.095^{* * *} \\
(0.044)\end{array}$ \\
\hline Household size & $\begin{array}{l}-0.021 \\
(0.095)\end{array}$ & $\begin{array}{l}-0.020 \\
(0.096)\end{array}$ & $\begin{array}{l}-0.040 \\
(0.095)\end{array}$ & $\begin{array}{l}0.015 \\
(0.093)\end{array}$ \\
\hline Obs. & 942 & 942 & 942 & 942 \\
\hline Prob $>$ chi 2 & 0.000 & 0.000 & 0.000 & 0.000 \\
\hline
\end{tabular}

Notes: Numbers in parentheses are standard errors. ${ }^{* * *},{ }^{* *}$, and ${ }^{*}$ indicate the levels of statistical significance at 1 percent, 5 percent, and 10 percent, respectively.

The findings confirm the results in Table 5. All variables - environmental attitude, environmental concern, warm glow, and self-expressive benefit - have similar sign and 
magnitude. Thus, environmental attitude, environmental concern, warm glow, and self-expressive benefit have positive influences on respondents' behavioral intention to purchase energy-saving appliances. Likewise, the only control variable, income, has significantly positive impacts on the intention to purchase energy-saving appliances. These results confirm that our findings are robust. Note that a similar explanation to age in the previous section can be applied to interpreting results from models 14 and 15 as well as all other models. In this case, the findings demonstrate that Environmental concern "Do you realize it is important to protect the environment?" has the relatively bigger impact than other variables in terms of the magnitude of the estimates in Table 6.

\section{Conclusion and Policy Implications}

In addition to top-down policies, changing human behavior - the bottom-up approach - is another way to conserve energy when the adverse effects of climate change are looming large. In this study, we assess the determinants of consumers' intention and the choice to purchase energy-saving appliances from the perspective of environmental attitude, concern, and psychological benefits. We narrow down on the purchase of energy-saving appliances and apply Probit models to a sample of 942 online survey responses collected in 2016.

Our findings suggest that behavioral intention has significant and positive effects on the choice to purchase energy-saving appliances. Further analysis indicates that environmental attitude and concern as well as psychological benefits have significantly positive impacts on respondents' behavioral intention to buy energy-saving appliances. One major insight is that in addition to the usual understanding that external, peer effect will increase environmentally friendly behavior, internal self-motivation can also be a key driver. Our paper's documentation 
that perceived psychological benefits positively affect behavioral intention is a first in kind for research on China. Furthermore, our findings show that age and household size are significantly and positively correlated with the decision to purchase energy-saving appliances.

Our study thus offers the following policy implications for promoting the purchase and adoption of energy-saving appliances in China. These implications are likely applicable to promote other environmentally friendly products. Behavioral intention offers a useful window into encouraging consumers' adoption of energy-saving appliances, and such intention is a mediator variable that is undergirded by consumers' environmental attitude and concern as well as psychological benefits. Therefore, policies that can change consumers' attitude and concern, or perceived psychological benefits, are conducive to promoting behavioral change. First, providing more relevant environmental information may shift consumers' environmental attitude. For example, the government or appliance vendors can make efforts to disseminate scientific evidence that energy scarcity and climate change are at least partly due to anthropogenic activities. Disseminating information such as atmospheric emissions, energy mix, and new renewable capacity installed may also shift consumers' attitude in favor of purchasing energy-efficient appliances (Johnson and Frank, 2006; Hartmann and Apaolaza-Ibáñez, 2012; Long et al., 2018). Second, boosting consumers' environmental concern via public campaigns and popular channels, such as primetime TV, is another sensible policy measure. Third, changing consumers' perceived psychological benefits of using energy-saving products through public 
advertising can help make consumers "feel good while doing well" socially and environmentally (Wiser, 1998; Hartmann and Apaolaza-Ibáñez, 2012). These efforts work together to influence consumers' environmental attitude and concern as well as perceived psychological benefits, and thereby, bending environmental intention towards the choice of purchasing energy-efficient appliances. Lastly, from the perspective of marketing energy-saving appliances, targeting larger households with more senior residents can increase the odds of adoption.

This study also provides directions for future research. For instance, future research can assess habitual energy-saving behavior other than the use of energy-saving appliances, such as turning off lights when leaving the room or shutting down the power when an appliance is not in use. Future research can also explore regional variations within China, given the known regional differences in the levels of economic development and educational attainment as well as divergences in preferences. To do that, future researchers can geolocate the respondents and explore geographical variations. To conclude, this study not only provides micro-level insights into promoting China's sustainable development but also offers a reference point for future research on purchasing energy-saving appliances in other countries, particularly developing countries.

\section{References}

Aaker, D.A. 2002. Building Strong Brands. New York: Free Press.

Aaker, J.L. 1999. The malleable self: the role of self-expression in persuasion. Journal of Marketing Research 36(1), 45-7.

Abrahamse, W., Steg, L. 2009. How do socio-demographic and psychological factors relate to households' direct and indirect energy use and savings? Journal of Economic Psychology 30, 711-720.

Ajzen, I. 1989. Attitude structure and behavior. Attitude structure and function 1, 241-274. 
Ajzen, I. 1991. The theory of planned behavior. Organizational Behavior and Human Decision Processes 50, 179-211.

Ali Research Report. 2016. Research Report on Taobao village of China in 2016. Ali Research Institute.

Andreoni, J. 1990. Impure altruism and donations to public goods: a theory of warm-glowing giving. The Economic Journal 100(401), 464-77.

Arvola, A., Vassallo, M., Dean, M., Lampila, P., Saba, A., Lähteenmäki, L., Shepherd, R. 2008. Predicting intentions to purchase organic food: The role of affective and moral attitudes in the Theory of Planned Behaviour. Appetite 50, 443-454.

Baldini, M., Trivella, A. 2018. Modelling of electricity savings in the Danish households sector: from the energy system to the end-user. Energy Efficiency 11, 1563-1581.

Baldini, M., Trivella, A., Wente, J.W. 2018. The impact of socioeconomic and behavioral factors for purchasing energy efficient household appliances: A case study for Denmark. Energy Policy 120, 503-513.

Bang, H.K., Ellinger, A., Hadjimarcou, J., Traichal, P. 2000. Consumer concern, knowledge, belief and attitude toward renewable energy: an application of the reasoned action theory. Psychology and Marketing 17 (6), 449-468.

Bennett, A., Chakravarti, A. 2009. The self and social signaling: explanations for consumption of CSR-associated products. Advances in Consumer Research 36, 49-50.

Biswas, A., Roy, M. 2015. Leveraging factors for sustained green consumption behavior based on consumption value perceptions: testing the structural model. Journal of Cleaner Production 95, 332-340.

Borchers, A.M., Duke, J.M., Parsons, G.R. 2007. Does willingness to pay for green energy differ by source? Energy Policy 35(6), 3327-3334.

Bray, J., Johns, N., Kilburn, D. 2011. An explanatory study into the factors impeding ethical consumption. Journal of Business Ethnics 98, 597-608.

Bergstrom, T., Blume, L.,Varian, H. 2006. On the private provision of public goods. Journal of Public Economics 29(1), 25-49.

Cai, S., Long, X., Li, L., Liang, H., Wang, Q., Ding, X. 2019. Determinants of intention and behavior of low carbon commuting through bicycle-sharing in China. Journal of Cleaner Production 212, 602-609

Chan, Y.K., Lau, B.Y. 2000. Antecedents of green purchases: a survey in China. Journal of Consumer Marketing 17 (4), 338-357.

Chen, M.F. 2016. Extending the theory of planned behavior model to explain people's energy savings and carbon reduction behavioral intentions to mitigate climate change in Taiwan-moral obligation matters. Journal of Cleaner Production 112, 1746-1753.

Chen, T.B., Chai, L.T. 2010. Attitude towards the Environment and Green Products: Consumers' Perspective. Management Science and Engineering 4 (2), 27-39.

China Environment Statistical Yearbooks. 2016. Various issues. Beijing: China Environmental Science Press.

CIA The World Factbook. Central Intelligence Agency. https://www.cia.gov/library/publications/the-world-factbook/fields/2212.html. Accessed 10 January 2018.

DeCicco, J., Yan, T., Keusch, F., Muñoz, D.H., Neidert, L. 2015. U.S. consumer attitudes and expectations about energy. Energy Policy 86, 749-758. 
Dillman, D., Smyth, J., Christian, J. 2009. Internet, Mail, and Mixed-Mode Surveys: The Tailored Design Methods, 3rd edition. John Wiley and Sons, Inc., New Jersey.

Ek, K. 2005. Public and private attitudes towards 'green' electricity: the case of Swedish wind power. Energy Policy 33(13), 1677-1689.

Ellen, P.S., Webb, D.J., Mohr L.A. 2006. Building corporate associations: Consumer attributions for corporate socially responsible programs. Journal of Academy of Marketing Science 34, 147-157.

Eurobarometer. 2005. Attitudes towards energy. A report produced by The European Commission for the Directorate-General for Research. Luxembourg.

Fishbein, M., Ajzen, I. 1975. Belief, Attitude, Intention, and Behavior:an Introduction to Theory and Research: Addison-Wesley Publishing Company 53.

Fransson, N., Gärling, T. 1999. Environmental concern: conceptual definitions, measurement methods, and research findings. Journal of Environmental Psychology 19, 369-382.

Friedman, M. 1957. The Permanent Income Hypothesis. A Theory of the Consumption Function. Princeton University Press. ISBN 0-691-04182-2.

Gadenne, D., Sharma, B., Kerr, D., et al. 2011. The influence of consumers' environmental beliefs and attitudes on energy saving behaviors. Energy Policy (12), 7684-7694.

Gao, G., Chen, M., Wang, J. et al. 2019. Sufficient or insufficient: Assessment of the intended nationally determined contributions (INDCs) of the world's major greenhouse gas emitters. Frontier of Engineering Management. https://doi.org/10.1007/s42524-019-0007-6. Accessed 3 January 2018.

Gaspar, R., Antunes, D. 2011. Energy efficiency and appliance purchases in Europe: Consumer profiles and choice determinants. Energy Policy 39(11), 7335-7346.

Gerpott, T.J., Mahmudova, I., 2010. Determinants of green electricity adoption among residential customers in Germany. International Journal of Consumer Studies 34 (4), 464-473.

Griskevicius, V., Tybur, J.M., Van den Bergh, B., 2010. Going green to be seen: status, reputation, and conspicuous conservation. Journal of Personality and Social Psychology 98 (3), 392-404.

Grösche, P., Schröder, C., 2011. Eliciting public support for greening the electricity mix using random parameter techniques. Energy Economics 33 (2), 363-370.

Grunert, S.C., Juhl, H.J. 1995. Values, environmental attitudes, and buying of organic foods. Journal of Economic Psychology 16, 39-62.

Hansla, A., Gamble, A., Juliusson, A., Gärling, T. 2008. The relationships between awareness of consequences, environmental concern, and value orientations. Journal of Environmental Psychology 28(1), 1-9.

Hartmann, P., Apaolaza-Ibáñez, V. 2012. Consumer attitude and purchase intention toward green energy brands: The roles of psychological benefits and environmental concern. Journal of Business Research 65, 1254-1263.

Heckman, J. 1979. Sample Selection Bias as a Specification Error. Econometrica 47(1), $153-161$.

Johnson, B.B., Frank, P.G. 2006. Public understanding of environmental impacts of electricity deregulation. Energy Policy 34(12), 1332-43.

Kaenzig, J., Heinzle, S.L., Wüstenhagen, R. 2013. Whatever the customer wants, the customer 
gets? Exploring the gap between consumer preferences and default electricity products in Germany. Energy Policy 53, 311-322.

Lancaster, K. J. 1966. A New Approach to Consumer Theory. Journal of Political Economy 74, 132-157.

Li, Z., Shao, B., Shi, X., Sun, Y., Zhang, X. 2019. Structural transformation of manufacturing, natural resource dependence, and carbon emission reduction: Evidence of a threshold effect from China. Journal of Cleaner Production. 206: 920-927.

Lim, S., Flaxman, A., Danaei, G., Shibuya, K., et al. 2013. A comparative risk assessment of burden of disease and injury attributable to 67 risk factors and risk factor clusters in 21 regions. Lancet. https://doi.org/10.1016/S0140-6736(12)61766-8. Accessed 5 January 2018.

Litvine, D., Wüstenhagen, R. 2011. Helping "light green" consumers walk the talk: Results of a behavioral intervention survey in the Swiss electricity market. Ecological Economics 70, 462-474.

Liu, X., Wang, C., Shishime, T., Fujitsuka, T. 2012. Sustainable consumption: Green purchasing behaviours of urban residents in China. Sustainable Development 20, 293-308.

Long, C., Mills, B. F., Schleich, J. 2018. Characteristics or culture? Determinants of household energy use behavior in Germany and the USA. Energy Efficiency 11 777-798.

Ma, B., Yu, Y., \& Urban, F. (2018). Green transition of energy systems in rural China: National survey evidence of households' discrete choices on water heaters. Energy Policy, 113, 559-570. doi:10.1016/j.enpol.2017.11.046

McFadden, D. 1974. Conditional Logit Analysis of Qualitative Choice Behavior. In: Zarembka, P., Ed., Frontiers in Econometrics, Academic Press, Salt Lake City, 105-142.

Mi, L.Y., Gu, M., Yang, J., Yu,X.Y., Liu,Y. 2016. Empirical research on the psychological motivation factors of urban residents' low carbon oriented energy consumption behavior in Xuzhou city. Resources Science 38(4), 609-621

Nachmias,C.F., Nachmias, D. 2000. Research Methods in the Social Science[M]. Sixth Edition. Worth Publishers, 208-213.

Netherlands Environmental Assessment Agency (NEAA), 2008. China Now No. 1 in $\mathrm{CO}_{2}$ Emissions, USA in Second Position. http://www.mnp.nl/en/dossiers/Climatechange/moreinfo/ChinanownolinCO2emissionsUS Ainsecondposition.html $\square$ Accessed 2 January 2017.

Noblet, C.L., Teisl, M.F., Evans, K., Anderson, M.W., McCoy, S., Cervon, E. 2015. Public preferences for investments in renewable energy production and energy efficiency. Energy Policy 87, 177-186.

Oreg, S., Katz-Gerro, T. 2006. Predicting pro-environmental behavior cross-nationally: values, the theory of planned behavior, and value-belief-norm theory. Environment and Behavior 38 (4), 462-483.

Parikh, K. S., \& Parikh, J. K. (2016). Realizing potential savings of energy and emissions from efficient household appliances in India. Energy Policy, 97, 102-111. doi:10.1016/j.enpol.2016.07.005

Paul, J., Modi, A., Patel, J. 2016. Predicting green product consumption using theory of planned behavior and reasoned action. Journal of Retailing and Consumer Services 29, 123-134.

Pope III, C.A., Dockery, D.W. 2013. Air pollution and life expectancy in China and beyond. PNAS 110, 12861-12862.

Reuters, 4 March 4 2014. China to declare war on pollution, premier says, Available at: 
http://www.reuters.com/article/us-china-parliament-pollution-idUSBREA2405W20140305. Accessed 25 August 2016.

Sapci, O., Considine, T. 2014. The link between environmental attitudes and energy consumption behavior. Journal of Behavioral and Experimental Economics 52, 29-34.

Sardianou, E., Genoudi, P. 2013. Which factors affect the willingness of consumers to adopt renewable energies? Renewable Energy 57, 1-4.

Schultz, P.W., Shriver, C., Tabanico, J.J., and Khazian, A.M. 2004. Implicit connections with nature. Journal of Environmental Psychology 24, 31-42.

Shen, S.V. 2018. The Political Pollution Cycle. Available at SSRN: http://dx.doi.org/10.2139/ssrn.2822922. Accessed 2 December 2018.

Shi, X. 2014. Setting effective mandatory energy efficiency standards and labelling regulations: A review of best practices in the Asia Pacific region. Applied Energy 133, 135-143.

Shi, X. 2015. Application of best practice for setting minimum energy efficiency standards in technically disadvantaged countries: Case study of Air Conditioners in Brunei Darussalam. Applied Energy 157, 1-12.

Shimokawa, M., Tezuka, T. 2014. Development of the "Home Energy Conservation Support Program" and its effects on family behavior. Applied Energy 114, 654-662.

Sovacool, B.K. 2014. Diversity: energy studies need social science. Nature 511, 529-530.

Sun, Y., Xue, J., Shi, X., Wang, K., Qi, S., Wang, L., and Wang, C. 2019. A Dynamic and Continuous Allowances Allocation Methodology for the Prevention of Carbon Leakage: Emission Control Coefficients. Applied Energy. 236: 220-230.

Stern, P.C. 2011. Contributions of psychology to limiting climate change. American Psychologist 66 (4), 303.

Stern, P.C. 2014. Energy: we need all hands on deck. Nature 513 (7516), 33.

Vermeir, I., Verbeke, W. 2006. Sustainable food consumption: Exploring the consumer "attitude-behavioral intention" gap. Journal of Agricultural and Environmental Ethics 19, 169-194.

Wang, K, Wu, M, Sun, Y., Shi, X., Sun, A, and Zhang, P. Resource abundance, industrial structure, and regional carbon emissions efficiency in China. Resource Policy. 60:203-214

Wang, Z., Zhang, B., Ying, J., Zhang, Y. 2011. Determinants and policy implications for household electricity-saving behaviour: evidence from Beijing, China. Energy Policy 39, 3550-3557.

Wiser, R.H. 1998. Green power marketing: increasing customer demand for renewable energy. Utilities Policy 7(2), 107-19.

WHO. 2016. WHO Global Urban Ambient Air Pollution Database (update 2016). http://www.who.int/phe/health_topics/outdoorair/databases/cities/en/. Accessed 2 January 2017.

Wooldrige, J.M. 2001, “Introductory Econometrics: A Modern Approach,” South-Western College Publishing, a division of Thomson Learning. P461.

Wüstenhagen, R., Bilharz, M. 2006. Green energy market development in Germany: effective public policy and emerging customer demand. Energy Policy 34 (13), 1681-1696.

Zarnikau, J. 2003. Consumer demand for 'green power' and energy efficiency. Energy Policy 31(15), 1661-1672.

Zeng, L., Yu, Y., Li, J. 2014. China's Promoting Energy-Efficient Products for the Benefit of the People Program in 2012: Results and analysis of the consumer impact study. Applied 
Energy 133, 22-32.

Zhang, P., Shi, X., Sun, Y., Shao, S. and Cui, J. 2019. Have China's Provinces Achieved Their Targets of Energy Intensity Reduction? Reassessment Based on Nighttime Lighting Data. Energy Policy 128, 276-283

Zhao, C., Zhang, M., Wang,W. 2019. Exploring the influence of severe haze pollution on residents' intention to purchase energy-saving appliances. Journal of Cleaner Production 212, 1536-1543. 